\title{
worldview
}

A JOURNAL OF RELIGION AND INTERNATIONAL AFFAIRS

\section{POWER, POLITICS AND INTELLECTUALS}

It is a fearful idea that the outcome of the current debate on American foreign policy may be of crucial importance, but it is true nonetheless. The debate turns on fundamental questions and it seems increasingly possible that-in so far as historical events can do so-Vietnam will provide some of the harsh answers.

What part should the American public have in these debates, particularly the small segment whikh is composed of intellectuals? To many people the answer is clear. American citizens should obviously participate in these debates and the greater their ability and opportunity to comprehend the issues the greater is their responsibility to speak out. In this view, the intellectual has a specal obligation because he can, more readily than many others, articulate the issues that must be considered.

There is, however, another view which disputes this and which would urge intellectuals to stick to their last, which is not politics. A forceful and incisive presentation of this view was put forth by a British journalist, Henry Fairlie, in a recent issue of Commentary. In the course of analyzing the reactions of American intellectuals to President Johnson he referred to the way in which the American intellectual "was raped by President Kennedy."

"At all times, and no matter who exercises it, power is ugly and brutalizing: President Kennedy was allowed to make it appear attractive and redeeming. Power is shoddy: President Kennedy was allowed to glamorize it. Power is for the aged: President Kennedy was allowed to cast over it the magic of youth. Power is un-intellectual: President Kennedy was allowed to give it intellectual excitement. Power is safe only if it is exercised without enchantment, without claim to reason, and without pretense to virtue: President Kennedy was allowed to endow it with all three Power is, no doubt, necessary: President Kennedy was allowed to make it seem desirable."

The complaint here, Fairlie makes clear, is directed not at President Kennedy, who did only what a politician properly does, but against the intellectuals who failed to criticize and reject what was disguised as appealing. The intellectual fell, in this view, into the traps that await those intellectuals who allow themselves to be tempted away from "their gentle pursuits" in order to meddle with the conflicting demands of power. It is unlikely, according to Fairlie, that the intellectual will avoid such traps for he "cannot easily apprehend politics, and anything which tempts Kim to believe that he can make sense either of the political process or in the political process is dangerous both to him and to the politician...." He has other burdens, apparently, for "temperamentally the intellectual cannot bear a problem that is incapable of solution." He is also tempted to imagine that there is such a thing as a real national interest. A terrible example is Walter Lippmann who "claims not only that there is such a thing as America's real national interest (which is doubtful), but that it can be discovered (which is certainly untrue), and that the politician should make it his business to discover it and obey it (which is alarming)."

There are a number of points solidly made here and Fairlie, who has what is termed a tough mind, knows well how to support them. Nevertheless, there is much in his analysis that is open to question and much that must be temed inaccurate or at least inadequate. Fairlie himself exlibits many of the characteristics he attributes to the intelleetual, the need, for example, to tidy things up, to leave no ends untied. The distinctions he makes are simply too neat to fit the reality. If, in the above quotation about President Kennedy one were to substitute the word Churchill, only the reference to youth would strike a jarring note. For surely Churchill made power seem attractive and redeeming, surely he brought to it and bestowed upon it intellectual excitement. And if he himself was not enchanted by the use of power he did in his finest hours endow it with virtue, did assert that it was subject to reason, and did glamorize the Battle for 
Britain in such a fashion that it has not yet lost -and may never lose-its burnished glow. There is no doubt that what one termed "style" (before it fell into disrepute in political discussions) was a part of Churchill's real strength. Was it a fault in Churchill that he made politics look gracious, as did Kennedy? Would it have been a political virtue if he made politics look beastly, as does Johnson? The distinctions are not so neat, the loose ends do not so readily tie up.

The most crucial point in this debate, however, tums on whether the intellectual generally has a proper evaluation of power and whether he can apprehend the political process in which that power is wielded. This is a controversy that has a fairly long history and good prospects for a fairly long future. It is not difficult to offer many examples of intellectuals (and artists and poets) who have shown grievous misunderstanding of the political process and have fought for what in retrospect seem trivial, foolish and dangerous positions, who have criticized unwisely because they did not know the limitations within which the politician, the decision-maker, must act: But such a list does not constitute proof of the thesis that intellectuals are temperamentally unsuited to the political life. For not only could one draw up an impressive list of professional politicians whose records were equally damaging, but one could point out historical instances in which the intellectual operated in an effective political manner. It is true, of course, that one cannot continue a severe, academic life and become highly involved in the political process, but no one would wish to debate such an obvious point. The term intellectual, to have force and meanisg, must embrace more than the academic. It must embrace, for example, many of those who are today offering opinions-and, quite naturally, differing opinions-on the stakes in Vietnam and the proper course of U.S. foreign policy in Vietnam.

Should these intellectuals refrain from political activity? It is true that they may and frequently will offer advice and opinion that is based on less than complete knowledge of Vietnam, on less than complete understanding of the process by which the decisions will ultimately be made, on concepts such as "national interest" that some politicians will value only for their rhetorical use. This and more can be said in criticism and reservation. But such reservations do not lead to an inevitable conclusion that their voice in contemporary political debate is without value. If intellectuals, with all their limitations, were to withdraw from political debate, public discussion and occasional activity in order to leave the field to the supposedly tougher, more sophisticated politician, our public political life would be more barren than it is. And there is no reason to believe that the political decisions would be improved in efficiency or quality. It is not impossible for intellectuals to learn-even about such matters as power, the political process and decision making. It is indeed by public discussion of these matters as they apply to Vietnam that the political process and political stability of the United States will be enhanced.

\section{In the magazines}

In matters of foreign policy the U.S. government has abandoned "all ideology except the true and meaningful one of material progress," states Robert H. Welker in The Nation of November 1. Morality is "irrelevant" in the "corrent official line." He says that this "new line out of Washington" is based on the foliowing ill-conceived, though "not in the least implausible ${ }^{n}$ worldview:

${ }^{2} 1$. Plutaliom. The real world is multiform, complex, turbulent, imperfect, unpredictable; hence policies which are not to accord with 'reality' or 'the facts' must adapt to this plural rather than to any single reality. (Marxism, a 'rigid' philosophy, can never do this, but Americans bave always been adaptable, inclusive, free and easy.) Recognition of this pluralism must surely lead to

"2, Pragmotism. Policies must be discussed and undertaken on the basis of tentative conclusions, for jmmediate and even partial ends, and with a view to their effectiveness in a given situation-and not as part of some Grand Design. Take each situation as it comes; don't fit the facts to conform with your ideas, but let your ideas emerge from the facts. Hence there must be

"3. An End to Ideology. Ideological frameworks are outmoded in a pluralistic, imperfect world, and may be dangerous; they becloud rather than clarify issues; they make it difficult for the pragmatic Amer- 